УДК 631.8:631.559

(C) 2013

Писаренко П. В., доктор сільськогосподарських наук, професор

Полтавська державна аграрна академія

Москалець В. В., кандидат сільськогосподарських наук,

Москалець Т. 3., кандидат біологічних наук

Білоцерківський національний аграрний університет

Москалець В. І., стариий науковий співробітник

Носівська селекційно-дослідна станція

Інституту сільськогосподарської мікробіології і агропромислового комплексу НААНУ

\title{
ВПЛИВ БІОЛОГІЗОВАНОЇ АГРОТЕХНОЛОГІЇ ВИРОЩУВАННЯ ТРИТИКАЛЕ ОЗИМОГО НА ЕЛЕМЕНТИ СТРУКТУРИ УРОЖАЙНОСТІ ЗЕРНА
}

\section{Рецензент - доктор сільськогосподарських наук В. В. Лавров}

\begin{abstract}
Досліджено чутливість генотипів тритикале озимого до дії мікробних препаратів альбобактерину і діазобактерину за елементами структури урожайності, в результаті чого сортовий набір ияісї культури, який входив до дослідів, був диференційований за рівнем чутливості на дію біоатентів конкретного препарату на: чутливі (на діазобактерин: «АД 256», «Славетне»; на альбобактерин: «Вівате Носівський», "Ягуар», "Августо», "Славетне»); помірно-чутливі (на діазобактерин: «Августо») та нечутливі (на діазобактерин: «Вівате Носівський», "Ягуар», «ДАУ 5»; на альбобактерин: «АД 256», «ДАУ 5»). Доведено здатність тритикале озимого сортів «АД 256», «Славетне» та «Biвате Носівський» під впливом мікробних препаратів забезпечувати на чорноземі типовому малогумусному легкосуглинковому цеентрального Лісо-

степу Украӥни високу урожайність зерна (7-8 m/2a) за рахунок збільшення кількості квіток із головного колосу, кількості зерен із головного колосу та рослини, маси зерен із головного колосу та рослини, маси 1000 зерен.
\end{abstract}

Ключові слова: тритикале озиме, сорт, мікробні препарати, елементи структури урожайності зерна.

Постановка проблеми. Селекціонерами синтезований генофонд тритикале гексаплоїдного та октоплоїдного рівнів, господарська цінність компонентів якого $є$ основою для їх ефективного використання на виробництві та в селекції. Проте 3-поміж сортового набору потрібно відібрати ті, що наділені аддитивно «працюючими» полігенами. Для цього впродовж тривалого часу необхідно вивчати колекційні зразки за показниками адаптивності, продуктивності, резистентності до шкідників і хвороб у динаміці, невід'ємною частиною чого є проведення структур- ного аналізу. Основою останнього є урожайність - головний результативний показник реакції посівів агрофітоценозів на екологічні фактори впродовж вегетаційного періоду. Показники елементів структури урожайності зерна визначає низка чинників навколишнього природного середовища, в т. ч. агротехнологія вирощування та якість і своєчасність ऑї проведення [1]. Тому проблема регулювання елементів структури урожайності впродовж вегетаційного періоду залишається відкритою. Нині пріоритетними $є$ заходи з використання біологізованих елементів вирощування сільськогосподарських культур. У зв'язку з чим активізується функціональна діяльність алохтонної та автохтонної мікрофлори, поліпшується стан агрофіто- та мікробіоценозів у цілому $[2,12]$.

Аналіз останніх досліджень і публікацій, у яких започатковано розв'язання проблеми. Згідно $з$ літературними джерелами, урожайність зерна відображає кількість продуктивних стебел, маса зерна 3 колоса [14], озерненість колоса, виповненість зерна [13]. Проте показники урожайності не завжди співпадають із показниками продуктивності рослин [19]. Для тритикале показники продуктивності - залежно від агроекологічних факторів - коливаються в межах 82$521 \mathrm{r} / \mathrm{m}^{2}$ [3]. Зокрема, за умов водного дефіциту в посівах цієї культури формується значна чисельність стерильних квіток, щупле зерно, а між показниками продуктивного кущення, продуктивності колоса, рослини і маси 1000 зерен спостерігається сильне варіювання [9]. Продуктивність колоса, що визначається кількістю зерен, коливається в межах 41-56 штук [18]. Тому варіабельність кількості зерен у колосі тритикале 
озимого значно вища, ніж для пшениці озимої та жита озимого й залежить від властивостей сорту, погодно-кліматичних умов та ін. [7].

Показники довжини колоса і кількості колосків у колосі тритикале вважають стабільними, які, перш за все, визначаються генотиповими факторами й залежать від властивостей конкретного генотипу й, менш істотно, - від погоднокліматичних факторів року [10, 16], на відміну від показників продуктивного кущення, кількості зерен у колосі й маси 1000 зерен та ін., рівень яких залежить від еколого-географічних умов, погодно-кліматичного фактора вегетаційного періоду, якості та своєчасності проведення агротехнологічних заходів [15]. Зокрема, показники продуктивного кущення та маса зерна 3 колоса, яка формується за умов збалансованості взаємо- зумовлених параметрів маси 1000 зерен і кількості зерен із колоса, варіюють у межах 24,6-59,9 \% та 1,2-2,5 г відповідно [4, 6, 8]. Проте зерно тритикале за крупністю перевершує зерно жита озимого і пшениці озимої [10]. За умов достатньої вологозабезпеченості року крупність зерна за масою 1000 зерен на 29\% більша [17]. Отже, глибші дослідження щодо формування і мінливості основних компонентів урожайності $є$ необхідними 3 огляду на удосконалення агротехнічних заходів управління процесом формування високої урожайності та одержання екологічнобезпечної рослинницької продукції.

Мета досліджень - дослідити стан агрофітоценозу тритикале озимого за елементами структури урожаю зерна під впливом біологізованої агротехнології вирощування.
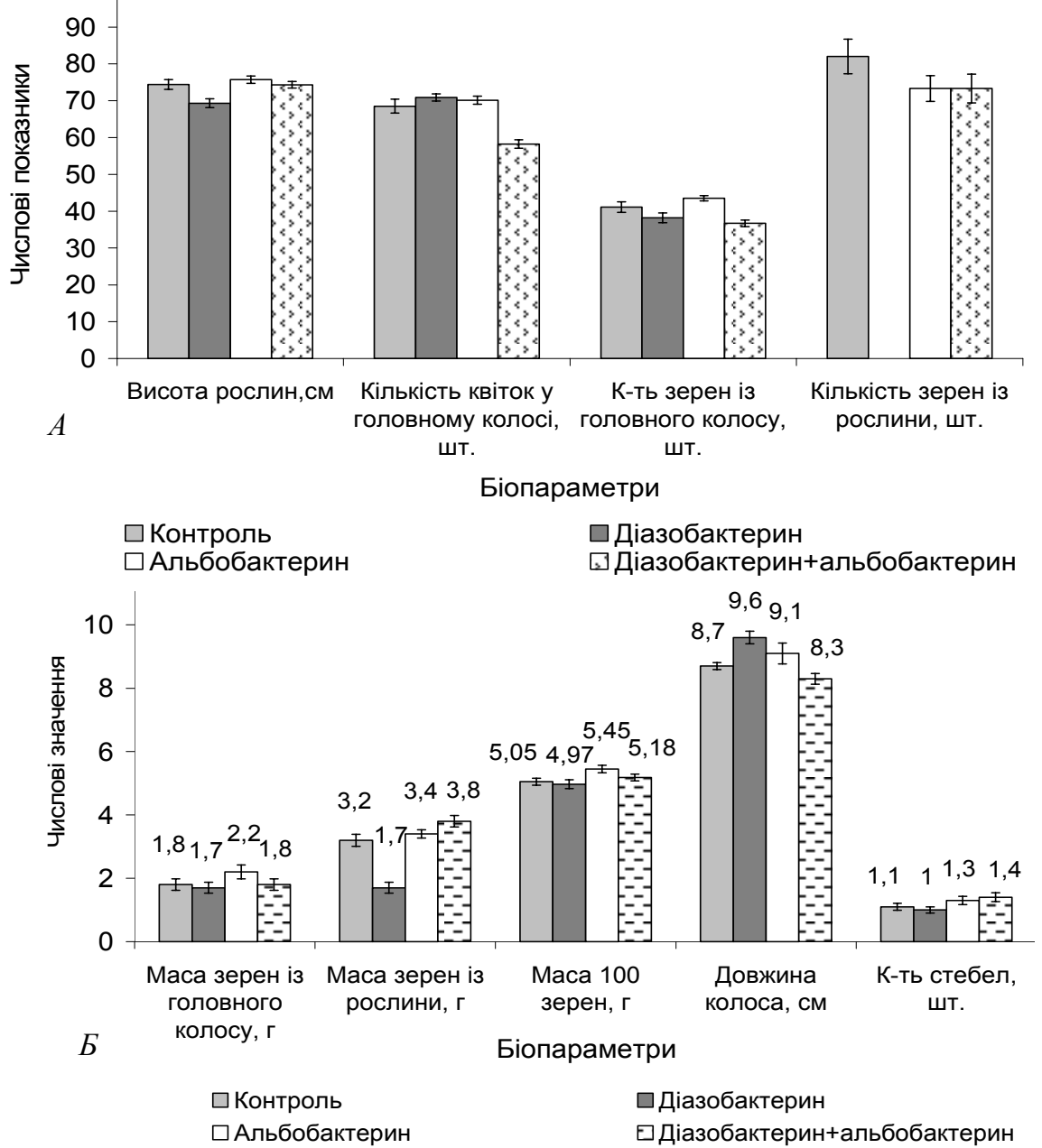

Рис. 1 А, Б. Чутливість посівів тритикале озимого сорту "Вівате Носівський» на дію мікробних препаратів за показниками елементів структури урожаю, ННДЦ БНАУ, середнс за 2008-2011 pp. 
Матеріали і методи досліджень. Польові та лабораторні дослідження проводили згідно з загальноприйнятими методами $[5,11]$.

Дослідження агротехнології вирощування проведено впродовж 2008-2012 pр. на стаціонарі навчально-наукового дослідного центру Білоцерківського національного аграрного університету (ННДЦ БНАУ), що в Київській області.

Дослід двохфакторний (фактор $A$ - сорт; фактор $B$ - біопрепарати), схема якого включала 4 варіанти: 1 - контроль; 2 - Діазобактерин; 3 - Альбобактерин; 4 - Діазобактерин + Альбобактерин.
Грунт дослідних ділянок - чорнозем типовий малогумусний легкосуглинковий на карбонатному лесі. Площа варіанту досліду становила $35 \mathrm{~m}^{2}$, облікова - $30 \mathrm{~m}^{2}$. Залежно від умов закладання досліду, попередниками для тритикале озимого були вико-вівсяна суміш і конюшина на зелену масу. Застосовували загальноприйняту для зони лісостепу технологію вирощування цієї культури. Назва сортів тритикале озимого, використаних у дослідах: «АД 256», «Славетне», «Вівате Носівський», «Ягуар», «Августо», «ДАУ 5». Математично-статистичну обробку даних здійснювали за О. Б. Доспєховим [5] та з використанням комп’ютерної програми Excel-2003.

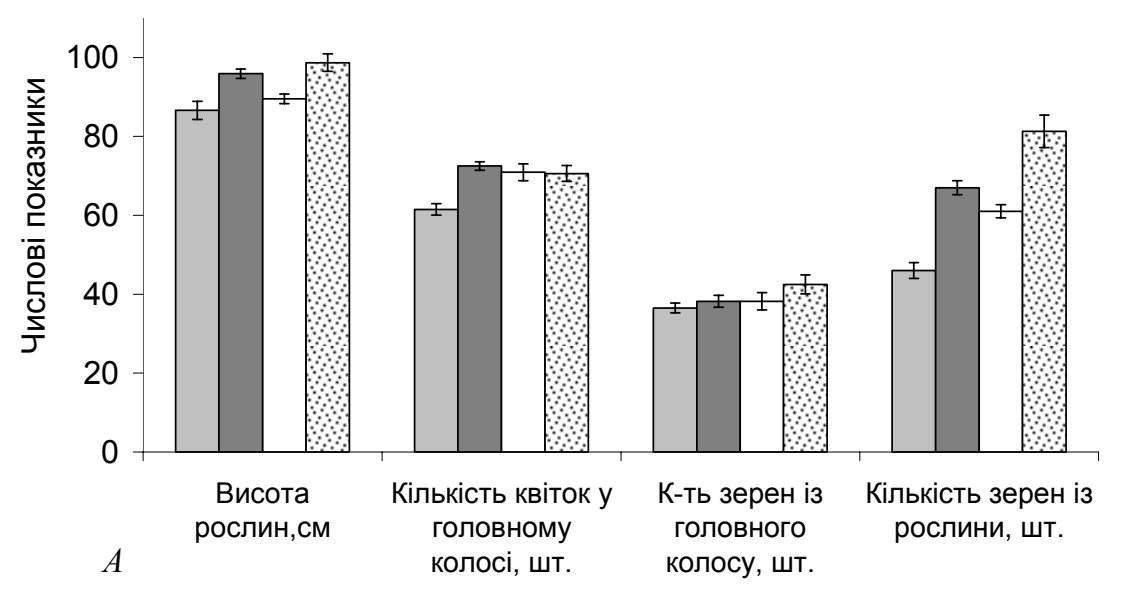

Біопараметри

$\square$ Контроль $\square$ Діазобактерин $\square$ Альбобактерин 요기азобактерин+альбобактерин

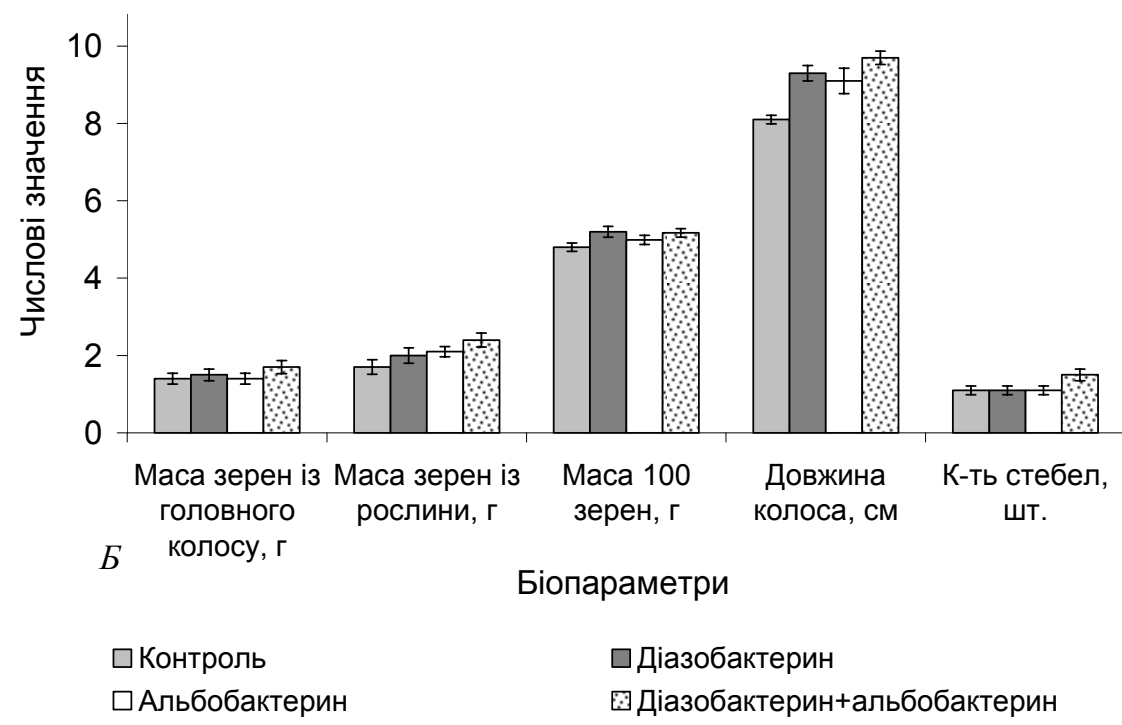

Рис. 2 А, Б. Чутливість посівів тритикале озимого сорту «Славетне» на дію мікробних препаратів за показниками елементів структури урожаю, ННДЦ БНАУ, середне за 2008-2011 pp. 
Результати досліджень. За результатами аналізу даних із визначення структурних елементів урожайності з'ясовано, що сорти тритикале озимого по-різному реагували на дію конкретного мікробного препарату за аналогічних агрокліматичних, грунтових і агротехнічних умов. Доведено, що ранньостиглий сорт тритикале озимого «Вівате Носівський» більш чутливий на дію альбобактерину, діючими біоагентами якого є фосфатмобілізуючі мікроорганізми Achromobacter album 1122, 3 огляду на показники кількості зерен із головного колосу, маси 1000 зерен та кількості продуктивних стебел (рис. 1 А, Б). Дані рисунка 1 свідчать про істотний вплив альбобактерину на щільність продуктивного стеблостою. Показники кількості продуктивних стебел на варіанті застосування фосфатмобілізуючих мікроорганізмів перевищують ті, що на контролі, в $1,2-1,3$ рази $(p \geq 0,05)$ відповідно.

Сортова специфічність на дію конкретного мікробного препарату проявляється незалежно від років досліджень. Сорт тритикале озимого «АД 256» виявився чутливим на дію азотфіксуючих бактерій препарату діазобактерину, зокрема за істотним $(p \geq 0,05)$ збільшенням кількості квіток у головному колосі, кількості зерен із головного колосу та рослини, маси зерен із головного колосу, маси зерен із рослини, довжини головного колосу та кількості продуктивних стебел із рослини. Істотний прояв чутливості посівів цього сорту на дію альбобактерину відмічено лише за показниками довжини колосу, які були в 1,1 разу більшими порівняно з контролем.

Середньостиглий сорт тритикале озимого «Славетне» видався більш чутливим на дію комплексу діазобактерину та альбобактерину, що суттєво позначилося на істотному збільшенні $(p=0,05)$ показників висоти рослин, кількості зерен із головного колосу та рослини, довжини колосу, маси зерен із головного колосу та рослини порівняно 3 контролем та варіантами моноінокуляції препаратами (рис. 2 А, Б).

Посіви сорту «ДАУ 5» не реагували на дію діазобактерину та альбобактерину. Попередні дослідження, проведені упродовж 2007-2009 рр.,

\section{БІБЛІОГРАФІЯ}

1. Білітюк А. П. Вирощування інтенсивних агроценозів тритикале в західних областях України: науково-методичні рекомендації / А. П. Білітюк. К. : Колообіг, 2006. - 208 с.

2. Біологічний азот: монографія / В. П. Патика, С. Я. Коць, В. В. Волкогон [та ін.]; за ред. В. П. Патики. - К. : Світ, 2003. - 424 с. показали, що цей сорт істотно реагує на дію фосфатмобілізуючих мікроорганізмів Bacillus polimyxa М поліміксобактерину.

Сорти «Августо» $\mathrm{i}$ «Ягуар» істотно реагували на дію альбобактерину. Зокрема, на посівах сорту «Августо» дія альбобактерину зумовила істотне $(p \geq 0,05)$ збільшення показників кількості продуктивних стебел - на 41,7 \%, висоти рослин - $11,3 \%$, довжини колоса $-7,1 \%$, кількості квіток із головного колоса $-2,5 \%$, кількості зерен із головного колосу та рослини - $17 \%$, маси зерен із головного колосу та рослини - 39,7 і 79,6 $\%$, маси 1000 зерен - 5,7\% порівняно з контролем. Отже, сорти тритикале озимого за показниками елементів структури урожайності зерна порізному реагують на дію конкретного біопрепарату.

\section{Висновки:}

1. За результатами досліджень сорти тритикале озимого були диференційовані за чутливістю на дію конкретних біопрепаратів. Для забезпечення оптимальних цільових параметрів урожаю зерна в умовах центрального Лісостепу на посівах тритикале озимого доцільно проводити передпосівну інокуляцію насіння ефективними штамами мікробних препаратів - Azospirillum brasilense - діазобактерину та Achromobacter album 1122 - альбобактерину, зокрема, на посівах тритикале озимого сорту «Славетне» застосовувати комплекс мікробних препаратів - діазобактерину та альбобактерину; на посівах сортів «Августо», «Ягуар», «Вівате Носівський» застосовувати альбобактерин; «АД 256» - діазобактерин, що істотно $(\mathrm{p} \geq 0,05)$ впливає на збільшення показників елементів структури урожайності зерна.

2. Виявлені особливості впливу біологізованої агротехнології вирощування на елементи структури урожайності тритикале озимого на території центрального Лісостепу. Це необхідно для уточнення флуктуації значень, тісноти зв'язків за інших екологічних умов, ефективного застосування мікробних препаратів залежно від сорту та збільшення виробництва екологічно-безпечної рослинницької продукції.

3. Бороданенко А. И. Результаты изучения коллекции тритикале на Кубани / А. И. Бороданенко, Н. В. Андрияш, Т. В. Охотникова // Генофонд пшеницы и тритикале в селекции сортов интесивного типа: Сб. науч. тр. по прикл. ботанике, генетике и селекции / ВИР. - Л., 1987. T. III. - C. 61-66. 
4. Дорофеев В. Ф. Исходный материал для селекции озимых тритикале в Нечерноземной зоне / В. Ф. Дорофеев, Н. Н. Чикида // Генофонд пшеницы и тритикале в селекции сортов интенсивного типа: Сб. науч. тр. по прикл. ботанике, генетике и селекции. - Л., 1987. - С. 66-71.

5. Доспехов Б. А. Методика полевого опыта / Б. А. Доспехов. - М. : Агропромиздат, 1995. - 352 c. 6. Касынкина О.М. Агробиологическая оценка исходного материала озимых тритикале в условиях Среднего Поволжья / О.М.Касынкина, Н. С. Орлова // Селекция и семеноводство с.-х. культур: Сб. ст. - Пенза, 1997. - С. 13-14.

7. Касынкина О. М. Новая культура - озимая тритикале для эколого-экономического кормопроизводства / О. М. Касынкина // Агроэкологические аспекты повышения эффективности сельскохозяйственного производства: Материалы юбилейной науч.-произв. конф. «Проблемы сельского хозяйства и пути их решения». - Пенза, 2001. - С. 73-74.

8. Кобылянский В. Д. Рожь. Генетические основы селекции / В. Д. Кобылянский // Всесоюз. акад. с.-х. наук им. В. И. Ленина. - М. : Колос, 1982. C. $180-193$.

9. Кумаков В. А. Структура фотосинтетического потенциала разных сортов яровой пшеницы / В. А. Кумаков // С.-х. биология. - 1968. - Т. 3. № 3. - C. 362-368.

10. Латыпов A. 3. Изменчивость хозяйственнополезных признаков у тритикале различного генетического происхождения / А. З. Латыпов, К. Х. Крус // Селекция интенсивных сортов полевых культур. - Горки, 1991. - С. 78-86.

11. Методика государственного сортоиспытания сельскохозяйственных культур. - М. : Колос, 1971. - Вып. 2. - 239 с.

12. Мікробні препарати у землеробстві. Теорія i практика: Монографія / В. В. Волкогон, О. В. Надкернична, Т. М. Ковалевська [та ін.] ; за ред. В. В. Волкогона. - К. : Аграрна наука, 2006. - 312 с. 13. Носатовський А. И. Пшениця / А. И. Носатовський. - М. : Колос, 1965. - 568 с.

14. Павлюк Н. Т. Перспективные образцы пшенично-ржаных амфидиплоидов для селекции на продуктивность в условиях Центрально-Черноземной зоны / Н. Т. Павлюк, Т. В. Камышова, А. Л. Веревкин // Биологические основы и методы селекции и семеноводства культурных растений: сб. науч. тр. - Воронеж, 1997. - С. 38-48.

15. Попов Г. И. Селекция озимой ржи / Г. И. Попов, В. Т. Васько, Н. Г. Пугач. - Л.: Агропромиздат, 1986. - $240 \mathrm{c}$.

16. Пшеничный A. E. Технологические свойства тритикале Амфидиплоид 206 / А. Е. Пшеничный, 3. Н. Сальникова // Селекция и семеноводство зерновых, зернобобовых и крупяных культур: науч. тр. - Каменная степь, 1978. - T. XV. - Вып. 3. C. 51-58.

17. Скорик B. B. Рекуррентная селекция озимой ржи на короткостебельность / В. В. Скорик // Селекция и семеноводство. - К., 1986. - Т. 61. C. 21-30.

18. Сюкова Г. А. Исходный материал для селекции короткостебельной озимой ржи в Степном Заволжье: дис. ... канд. с.-х. наук. / Г. А. Сюкова Л. : Пушкин, 1988. - 176 с.

19. Удачин Р. А. Мировой генофонд озимых октои гексаплоидных тритикале как исходный материал для создания новых сортов пшенично-ржаных амфидиплоидов / Р. А. Удачин, Т. В. Камышова, А. Л. Веревкин // Селекционно-генетические основы повышения урожайности зерновых и кормовых культур в Центрально-Черноземной зоне: сб. науч. тр. - Воронеж, 1993. - С. 36-42. 